\author{
Research Article
}

\title{
A COMPARATIVE CLINICAL STUDY OF KHANDA SHUNTHI AND PRASARNI AVLEHA IN THE MANAGEMENT OF AMAVATA WITH SPECIAL REFERENCE TO RHEUMATOID ARTHRITIS
}

\begin{tabular}{|c|c|}
\hline \multicolumn{2}{|r|}{$*$} \\
\hline & $\begin{array}{l}\text { Background: Amavata is the most common form of inflammatory arthopathy seen in India. } \\
\text { Among adult population below the age of } 50 \text { years this is the most common form of } \\
\text { arthritis. For the present study, on Amavata as shaman therapy, Khanda Shunthi and } \\
\text { Prasarni Avleha the Ushnaveeryadravya medicaments were chosen. } \\
\text { Aims \& Objective: The present research work aimed at to evaluate efficacy and establish } \\
\text { safe use of Khanda Shunthi and Prasarni Aavaleha in Amavata. } \\
\text { Materials \& Methods: } 40 \text { subjects of Amavata fulfilling the inclusion criteria were selected } \\
\text { from OPD and IPD of Desh Bhagat Ayurvedic Hospital, Mandi Gobindgarh, Punjab and } \\
\text { randomly divided into two groups, group A and B, comprising each of } 20 \text { patients. Group-A } \\
\text { subjects received Khanda Shunthi for } 60 \text { days, Group-B subjects received Prasarni Avaleha } \\
\text { for } 60 \text { days. Assessments were done on } 0^{\text {th }} \text { and } 60^{\text {th }} \text { day of treatment. } \\
\text { Results and Conclusions: In both the groups, highly significant results were observed in } \\
\text { all the cardinal parameters with P value for fever and Hb are greater than } 0.05 \text { hence there } \\
\text { is no significant difference in effect of Group A and Group B on fever and Hb. P values for all } \\
\text { other symptoms are less than } 0.05 \text { hence we conclude that there is significant difference in } \\
\text { effect of group A and group B on pain, swelling, stiffness, fever, ESR, walking time and grip } \\
\text { strength. On comparison group A treatment is more effective than group B for all } \\
\text { assessment criteria. }\end{array}$ \\
\hline
\end{tabular}

\section{INTRODUCTION}

Ayurveda, the ancient medical science of India has got the treasure of effective remedies for various chronic and intractable diseases. Because of changing lifestyle, social structure, environment and dietary habits of modern era incidences of many ailments are increasing day by day. Growing occurrence of Amavata is also one of the outcomes of this new way of life. It is a common chronic inflammatory joint disease in which joints become swollen, painful, and stiff. It is a debilitating illness considering its chronicity and complications. On the basis of etiology and clinical features Amavata can be correlated with Rheumatoid arthritis (RA).

\begin{tabular}{|l|l|}
\hline \multicolumn{3}{|c|}{ Access this article online } \\
\hline Quick Response Code & \\
\hline
\end{tabular}

Rheumatoid arthritis (RA) is the most common form of inflammatory arthropathy seen in India. Among adult population below the age of 50 years this is the most common form of arthritis. There are several reports on the frequency of RA in different populations group. A study from West Bengal (1997) gave the prevalence rate as 4.48 to 4.63 per 1000 populations. Seropositive disease occurred in twothird among them. The prevalence of RA is $0.5 \%$ of the Indian population. In the rural part it is $0.7 \%$. Among the connective tissue disease, RA is by far the commonest. [1]

The word Amavata is made up of a combination of two words, Ama and Vata.[2] The disease is mainly due to derangement of Agni, including, Jatharagni, Dhatvagni and Bhutagni, which results in the formation of Ama. Ama gets circulated throughout the body by the vitiated Vata dosha and track down in the Sandhis (joints), causing swelling, pain, tenderness and stiffness over the big and small joints. ${ }^{[3]}$ 
Anu Gupta, Kalpana Patni. A Comparative Clinical Study of Khanda Shunthi and Prasarni Avleha in the Management of Amavata

Therefore, it has taken the foremost place among the joint disorders. It continues to pose challenge to physician due to severe morbidity and crippling nature and claiming the maximum loss of human power making it a biggest world wise burning problem irrespective of races.

For the present study, on Amavata as Shamana therapy with "Khanda Shunthi" and "Prasarniavleha" the Ushna Veerya Dravya medicaments were used. The drugs are mentioned in Bhavaprakash Madhyam Khanda in the context of Amavata.

\section{Trial Drugs}

Khanda Shunthi and Prasarni Avleha are mentioned in Bhava Prakash (Madhyam Khanda) under Aamavata rogadhikara were used for trial.

Table 1: Khanda Sunthi- Main ingredients of Khanda Shunthi

\begin{tabular}{|c|l|l|l|}
\hline S.No. & Ingredients of Khand Shunti & Part used & Proportion \\
\hline 1 & Shunthi (Zingiber officinale) & Rhizome & 32 parts \\
\hline 2 & Go Ghrita & Cow's Ghee & 80 parts \\
\hline 3 & Go Dugdha & Cow's milk & 128 parts \\
\hline 4 & Khanda Sharkara & Sugar candy & 200 parts \\
\hline Prakshep dravya & Rhizome & 1 Part \\
\hline 1 & Shunthi (Zingiber officinale) & Fruit & 1 Part \\
\hline 2 & Maricha (Piper nigrum) & Fruit & 1 Part \\
\hline 3 & Pippali (Piper longum) & Bark & 1 Part \\
\hline 4 & Twak (Cinnamomum zeylanicum) & Leaf & 1 Part \\
\hline 5 & Tejapatra (Cinnamomum tamal) & Fruit & 1 Part \\
\hline 6 & Ela (Elettaria cardamomum) & \multicolumn{2}{l}{} \\
\hline
\end{tabular}

\section{Main Ingredients of Khanda Shunthi}

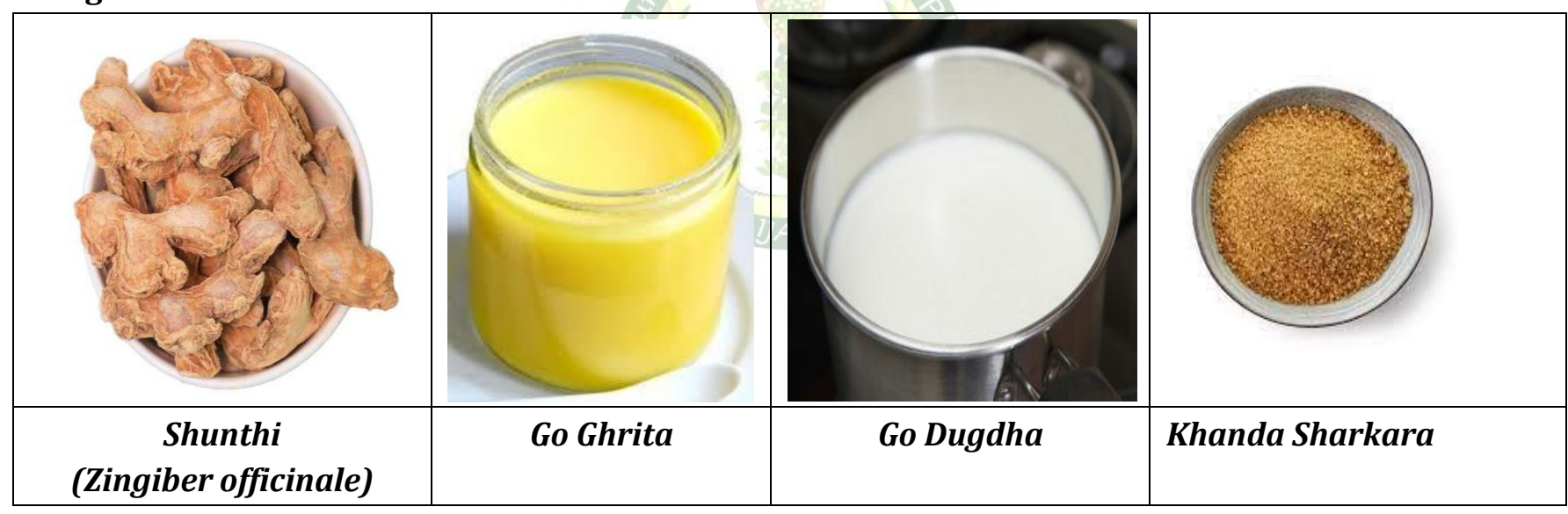

Table 2: Prasarni Avleha - Main ingredients of Prasarni Avleha

\begin{tabular}{|c|c|c|c|}
\hline S.No. & Ingredients & Part used & Proportion \\
\hline 1 & Prasarni kwatha (Paederia foetida) & Whole Plant & 1 Adhaka $(2.56 \mathrm{~kg})$ \\
\hline 2 & Guda (Jaggery) & - & 1 Prastha (80 grams) \\
\hline \multicolumn{4}{|c|}{ Prakshep dravya } \\
\hline 1 & Pippali (Piper longum) & Fruit & 1 Part \\
\hline 2 & Pippalimoola (Piper longum) & Root & 1 Part \\
\hline 3 & Chavya (Piper chaba) & Fruit & 1 Part \\
\hline 4 & Chitraka (Plumbago zeylenica) & Root & 1 part \\
\hline 5 & Shunthi (Zingiber officinale) & Rhizome & 1 Part \\
\hline
\end{tabular}




\section{Main Ingredients of Prasarini Avaleha}

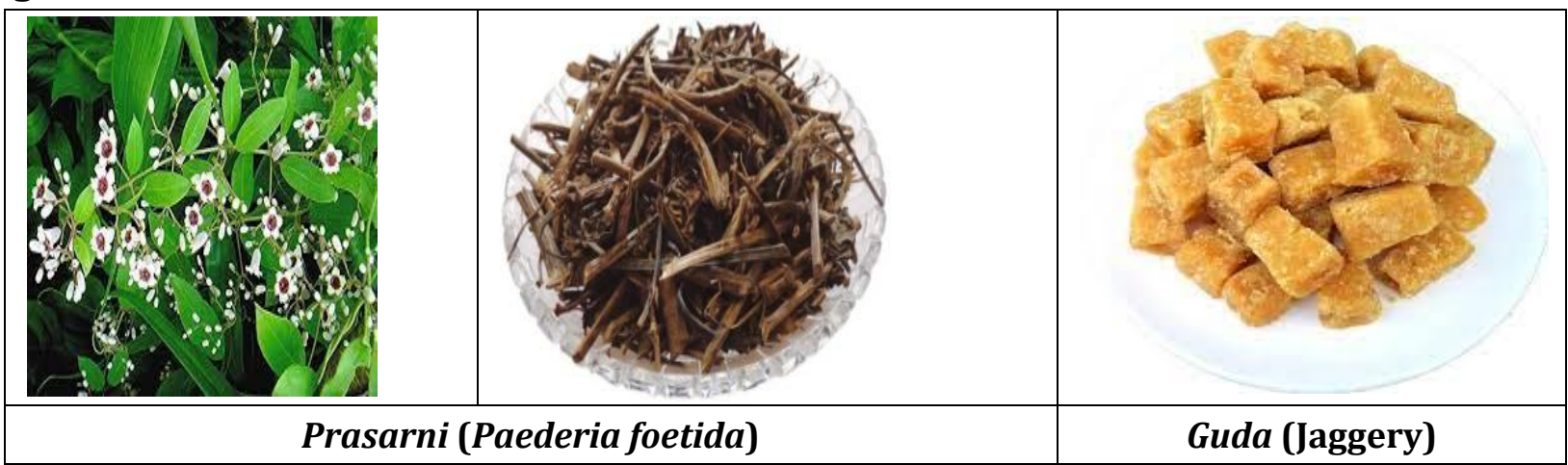

Khanda Shunthi and Prasarni Avaleha were prepared in Desh Bhagat Ayurvedic Pharmacy, Mandi, Gobindgarh, Punjab. The quality of ingredients and final product was ensured by the experts from the Department of Dravyaguna and Rasashasrta of the Institution.

\section{AIM AND OBJECTIVES}

1. To review concept, etiopathogenesis and principles of management of disease Amavata (R.A) from both Ayurvedic and modern point of view.

2. To evaluate the efficacy of Khanda-Shunthi in Amavata.

3. To evaluate the efficacy of Prasarni Avaleha in Amavata.

4. To establish safe and effective medicine for treatment of Amavata.

\section{MATERIAL AND METHODS}

The present study comprises of two components as follows:

- Demographic and clinical study in Amavata patients.

- Clinical assessment of therapeutic study of trial drugs in patients of Amavata.

\section{Hypothesis}

- Will there be any significant difference between the efficacy of Khanda Sunthi and Prasarni Avleha during the management of Amavata.

- $\mathrm{H}_{0}$ : There will be no significant difference between the efficacy of Khanda Sunthi and Prasarni Avleha in both the trial groups at 0.05 level of significance.

- $\mathrm{H}_{1}$ : There will be significant difference between the efficacy of Khanda Shunthi and Prasarni avleha in both the trial groups at 0.05 level of significance.

\section{Clinical Study}

Patients suffering from Amavata were selected from OPD Desh Bhagat Ayurvedic Pharmacy, Mandi Gobindgarh and IPD of Desh Bhagat Hospital, Mandi Gobindgarh, Punjab, after fulfilling the inclusion and exclusion criteria.

\section{Clinical Data}

\section{Sample size}

Total number of patients taken for study were 40 excluding dropouts of Amavata were selected from
OPD/ IPD of Desh Bhagat Hospital, Mandi, Gobindgarh (PB).

Study Design: Randomized, Parallel group, comparative trial.

- Screening: 57 patients were attending the OPD/ IPD of Kayachikitsa department with symptoms and signs of Amavata i.e., Rheumatoid Arthritis considered for inclusion in the study.

- Consent: Written and informed consent of patients had taken before inclusion in the trial.

- Enrolment: 49 Screened Amavata patients, who will give their consent and fulfil the inclusion criteria be selected for the study.

\section{Grouping of Patients}

There will be only two group's i.e.

Trial Group A: 20 patients were selected for the trial in this group. Khanda Shunthi was given in the dose of $10 \mathrm{gm}$. Two times a day with lukewarm water.

Trial Group B: 20 patients were selected for the trial. Prasarni avleha was given to patients of this group in the dose of $10 \mathrm{gm}$. Twice a day with lukewarm water.

Dropout Patients- 9 patients

40 Patients were participated for complete clinical trial.

Follow-up: All the patients were called for follow-up after every 15 days.

Final Study Visit: All patients were assessed clinically after completion of the trial (i.e. after 60 days)

- Duration of trial: The total duration of the trial drug is 60days with evaluation at intervals of every 15 days.

- Follow-up: The patients after putting into trial advised to come for follow up after every $15^{\text {th }}, 30^{\text {th }}$, $45^{\text {th }}$, and $60^{\text {th }}$ days.

\section{Inclusion Criteria}

1. Patients of Amavata with the history less than 5 years.

2. Both male female patients age between 15 to 65 years.

3. Patients having signs and symptoms of Amavata of any Dosha Anubandha mentioned in Ayurvedic text and modern text. 


\section{Exclusion Criteria}

1. A patient of Amavata having history of more than 5 years.

2. Patient below 15 and above 65 years of the age

3. Patients with complications like deformity, loss of functions and Granthi

4. Pregnant women and lactating mother

5. Patients with Rheumatic fever

6. RA of Spine

7. Patients of Amavata having the systemic diseases.

Parameters for assessment

\section{Subjective Parameters}

The Symptoms of Amavata in Ayurvedic text and modern texts like Shoola, Shotha, Jadya, Vaivarnyata.

Joint Pain (Sandhi Shoola)

Table 3: Showing Joint Pain Grading

\begin{tabular}{|c|l|}
\hline Score & Joint Pain Status \\
\hline 0 & No Pain \\
\hline 1 & Mild Pain \\
\hline 2 & Pain on movement \& relieved on rest \\
\hline 3 & Constant Pain \\
\hline 4 & Severe Pain disturbing sleep \\
\hline
\end{tabular}

Swelling of Joints (Sandhi Shotha)

Table 4: Showing Sandhi shotha grading

\begin{tabular}{|c|l|}
\hline Score & Status \\
\hline 0 & No Swelling \\
\hline 1 & Mild Swelling \\
\hline 2 & Moderate Swelling \\
\hline 3 & Severe Swelling without loss of movements \\
\hline 4 & Severe Swelling with loss of movements \\
\hline
\end{tabular}

\section{Stiffness (Stabdhata)}

Table 5: Showing Stiffness Grading

\begin{tabular}{|c|l|}
\hline Score & Status \\
\hline 0 & No stiffness \\
\hline 1 & Stiffness lasting for few minutes to 1 hour \\
\hline 2 & Stiffness lasting for 1to 8 hours \\
\hline 3 & $\begin{array}{l}\text { Stiffness lasting for more than 8 hours but } \\
\text { not through-out the day }\end{array}$ \\
\hline 4 & Throughout the day \\
\hline
\end{tabular}

STATISTICAL ANALYSIS

Study statistically analyzed with Wilcoxon matched pairs test, Mann-Whitney U test.

Outcome of Therapies on Shula (Pain)

Table 10: Table-Outcome of Therapies on Shula (Pain)

\begin{tabular}{|c|c|c|c|c|c|c|}
\hline \multirow{2}{*}{ Pain } & \multicolumn{2}{|c|}{ Median } & \multirow{2}{*}{$\begin{array}{l}\text { Wilcoxon Signed } \\
\text { Rank }\end{array}$} & \multirow{2}{*}{ P-Value } & \multirow{2}{*}{ \% Effect } & \multirow{2}{*}{ Result } \\
\hline & BT & AT & & & & \\
\hline Group A & 3 & 0.5 & $-4.028^{a}$ & 0.000 & 82.8 & Significant \\
\hline Group B & 3 & 1 & $-3.992^{a}$ & 0.000 & 66.7 & Significant \\
\hline
\end{tabular}

Table 6: Showing fever grading:

\begin{tabular}{|l|l|}
\hline Score & Status \\
\hline 0 & No Fever \\
\hline 1 & Mild fever \\
\hline 2 & Moderate fever \\
\hline 3 & High fever \\
\hline
\end{tabular}

\section{Objectives Parameters}

1. $\mathrm{Hb} \%$

2. ESR

3. Walking time

4. Grip strength

Grip strength: Patient's grip strength is assessed before and after treatment according to the readings in the grip strength meter in terms of pound.

\section{Haemoglobin}

Table 7: Showing Haemoglobin

\begin{tabular}{|l|l|}
\hline Haemoglobin gm $\%$ & Grade \\
\hline 12.5 or more & 0 \\
\hline 12.4 to $11 \mathrm{gm} \%$ & 1 \\
\hline 10.9 to $9.5 \mathrm{gm} \%$ & 2 \\
\hline Less than $9.5 \%$ & 3 \\
\hline
\end{tabular}

Table 8: Showing ESR Grading

\begin{tabular}{|l|l|l|}
\hline ESR & Lab Value $\mathbf{( m m} / \mathbf{h})$ & Grade \\
\hline Normal & Upto 7 & 0 \\
\hline Mild & $7-10$ & 1 \\
\hline Moderate & $10-15$ & 2 \\
\hline Severe & Above 15 & 3 \\
\hline
\end{tabular}

Walk Time

Table 9: Showing Walks Time

\begin{tabular}{|l|l|}
\hline Walk time (for 25 feet) & Grade \\
\hline$>40$ second or more & 0 \\
\hline $31-40$ second & 1 \\
\hline $21-30$ second & 2 \\
\hline $15-20$ second & 3 \\
\hline
\end{tabular}


Int. J. Ayur. Pharma Research, 2021;9(Suppl 1):20-26

It is observed that P-Values for both the study groups are $<0.05$ hence we conclude that the effect observed in both groups are significant. Further we can observe that, effect observed in Group A was $82.8 \%$ while effect observed in Group B was 66.7\%.

Outcome of Therapies on Shotha (Swelling)

Table 11: Outcome of Therapies on Shotha (Swelling)

\begin{tabular}{|c|c|c|c|c|c|c|}
\hline \multirow{2}{*}{ Swelling } & \multicolumn{2}{|c|}{ Median } & \multirow{2}{*}{$\begin{array}{l}\text { Wilcoxon Signed } \\
\text { Rank W }\end{array}$} & \multirow{2}{*}{$\begin{array}{l}\text { P- } \\
\text { Value }\end{array}$} & \multirow{2}{*}{ \% Effect } & \multirow{2}{*}{ Result } \\
\hline & BT & AT & & & & \\
\hline Group A & 3.5 & 1 & $-3.992^{a}$ & 0.000 & 75.4 & Significant \\
\hline Group B & 3 & 1 & $-4.088^{a}$ & 0.000 & 67.8 & Significant \\
\hline
\end{tabular}

It is observed that P-Values for both the groups are $<0.05$ hence we conclude that the effect observed in both groups are significant. Further we can observe that, effect observed in Group A was 75.4\% while effect observed in Group B was 67.8\%.

Outcome of Therapies on Stabdhta (Stiffness)

Table 12: Outcome of Therapies on Stabdhta (Stiffness)

\begin{tabular}{|l|l|l|l|l|l|l|}
\hline \multirow{2}{*}{ Stiffness } & \multicolumn{2}{|l|}{ Median } & Wilcoxon Signed & P-Value & \% Effect & Result \\
\cline { 2 - 7 } & BT & AT & Rank W & & & \\
\hline Group A & 3 & 0.5 & $-3.998^{a}$ & 0.000 & 82.8 & Significant \\
\hline Group B & 3 & 1 & $-4.008^{a}$ & 0.000 & 63.9 & Significant \\
\hline
\end{tabular}

It is observed that P-Values for both the groups are $<0.05$ hence we conclude that the effect observed in both groups are significant. Further we can observe that, effect observed in Group A was 82.8\% while effect observed in Group B was 63.9\%.

Outcome of Therapies on Jwara (Fever)

Table 13: Outcome of Therapies on Jwara (Fever)

\begin{tabular}{|c|c|c|c|c|c|c|}
\hline \multirow{2}{*}{ Fever } & \multicolumn{2}{|c|}{ Median } & \multirow{2}{*}{$\begin{array}{l}\text { Wilcoxon Signed } \\
\text { Rank W }\end{array}$} & \multirow{2}{*}{ P-Value } & \multirow{2}{*}{$\%$ Effect } & \multirow{2}{*}{ Result } \\
\hline & BT & AT & & & & \\
\hline Group A & 3 & 0 & $-4.042^{a}$ & 0.000 & 86.8 & Significant \\
\hline Group B & 3 & 1 & $-4.056^{a}$ & 0.000 & 75.9 & Significant \\
\hline
\end{tabular}

It is observed that P-Values for both the groups are $<0.05$ hence we conclude that the effect observed in both groups are significant. Further we can observe that, effect observed in Group A was $86.8 \%$ while effect observed in Group B was 75.9\%.

Outcome of Therapies on Hemoglobin

Table 14: Outcome of Therapies on Hemoglobin

\begin{tabular}{|c|c|c|c|c|c|c|}
\hline \multirow{2}{*}{ HB } & \multicolumn{2}{|c|}{ Median } & \multirow{2}{*}{$\begin{array}{l}\text { Wilcoxon Signed } \\
\text { Rank W }\end{array}$} & \multirow{2}{*}{ P-Value } & \multirow{2}{*}{$\%$ Effect } & \multirow{2}{*}{ Result } \\
\hline & BT & AT & & & & \\
\hline Group A & 3 & 0.5 & $-4.058^{a}$ & 0.000 & 81.1 & Significant \\
\hline Group B & 3 & 1 & $-4.089 a$ & 0.000 & 71.7 & Significant \\
\hline
\end{tabular}

It is observed that P-Values for both the groups are $<0.05$ hence we conclude that the effect observed in both groups are significant. Further we can observe that, effect observed in Group A was 81.1\% while effect observed in Group B was 71.7\%.

Outcome of Therapies on ESR

Table 15: Outcome of Therapies on ESR

\begin{tabular}{|c|c|c|c|c|c|c|}
\hline \multirow{2}{*}{ ESR } & \multicolumn{2}{|c|}{ Median } & \multirow{2}{*}{$\begin{array}{l}\text { Wilcoxon } \text { Signed } \\
\text { Rank W }\end{array}$} & \multirow{2}{*}{ P-Value } & \multirow{2}{*}{$\%$ Effect } & \multirow{2}{*}{ Result } \\
\hline & BT & AT & & & & \\
\hline Group A & 3 & 0.5 & $-4.035^{\mathrm{a}}$ & 0.000 & 81.5 & Significant \\
\hline Group B & 3 & 1 & $-4.072^{a}$ & 0.000 & 64.7 & Significant \\
\hline
\end{tabular}

It is observed that P-Values for both the groups are $<0.05$ hence we conclude that the effect observed in both groups are significant. Further we can observe that, effect observed in Group A was 81.5\% while effect observed in Group B was 64.7\%. 


\section{Outcome of Therapies on walking time}

Table 16: Outcome of Therapies on walking time

\begin{tabular}{|l|l|l|l|l|l|l|}
\hline \multirow{2}{*}{$\begin{array}{l}\text { Walking } \\
\text { time }\end{array}$} & \multicolumn{2}{|l|}{ Median } & Wilcoxon & P-Value & \% Effect & Result \\
\cline { 2 - 7 } & BT & AT & Signed Rank W & & & \\
\hline Group A & 3 & 0 & $-4.064^{a}$ & 0.000 & 83.3 & Significant \\
\hline Group B & 3 & 1 & $-4.134^{a}$ & 0.000 & 68.6 & Significant \\
\hline
\end{tabular}

It is observed that P-Values for both the groups are $<0.05$ hence we conclude that the effect observed in both groups are significant. Further we can observe that, effect observed in Group A was 83.3\% while effect observed in Group B was 68.6\%.

\section{Outcome of Therapies on Grip strength}

Table 17: Outcome of Therapies on Grip strength

\begin{tabular}{|c|c|c|c|c|c|c|}
\hline \multirow{2}{*}{$\begin{array}{l}\text { Grip } \\
\text { strength }\end{array}$} & \multicolumn{2}{|c|}{ Median } & \multirow{2}{*}{$\begin{array}{l}\text { Wilcoxon Signed } \\
\text { Rank W }\end{array}$} & \multirow{2}{*}{ P-Value } & \multirow{2}{*}{$\%$ Effect } & \multirow{2}{*}{ Result } \\
\hline & BT & AT & & & & \\
\hline Group A & 3 & 0 & $-4.053^{a}$ & 0.000 & 87.3 & Significant \\
\hline Group B & 3 & 1 & $-4.064^{\mathrm{a}}$ & 0.000 & 70.0 & Significant \\
\hline
\end{tabular}

It is observed that P-Values for both the groups are $<0.05$ hence we conclude that the effect observed in both groups are significant. Further we can observe that, effect observed in Group A was 87.3\% while effect observed in Group B was 70\%.

Table 18: Effect of Therapies Comparison between the Groups

\begin{tabular}{|c|c|c|c|c|c|c|}
\hline Parameter & Group & $\mathbf{N}$ & Mean Rank & Sum of Ranks & Mann Whitney U & P-Value \\
\hline \multirow{3}{*}{ Pain } & Group A & 20 & 25.13 & 502.50 & \multirow{3}{*}{107.500} & \multirow{3}{*}{0.006} \\
\hline & Group B & 20 & 15.88 & 317.50 & & \\
\hline & Total & 40 & & 28 & & \\
\hline \multirow{3}{*}{ Swelling } & Group A & 20 & 24.90 & 498.00 & \multirow{3}{*}{112.000} & \multirow{3}{*}{0.008} \\
\hline & Group B & 20 & 16.10 & 322.00 & & \\
\hline & Total & 40 & & $2+1$ & & \\
\hline \multirow{3}{*}{ Stiffness } & Group A & 20 & 25.30 & 506.00 & \multirow{3}{*}{104.000} & \multirow{3}{*}{0.005} \\
\hline & Group B & 20 & 15.70 & 314.00 & & \\
\hline & Total & 40 & & Q1PTS & & \\
\hline \multirow{3}{*}{ Fever } & Group A & 20 & 22.58 & 451.50 & \multirow{3}{*}{158.500} & \multirow{3}{*}{0.190} \\
\hline & Group B & 20 & 18.43 & 368.50 & & \\
\hline & Total & 40 & & & & \\
\hline \multirow{3}{*}{$\mathrm{HB}$} & Group A & 20 & 22.60 & 452.00 & \multirow{3}{*}{158.000} & \multirow{3}{*}{0.170} \\
\hline & Group B & 20 & 18.40 & 368.00 & & \\
\hline & Total & 40 & & & & \\
\hline \multirow{3}{*}{ ESR } & Group A & 20 & 24.95 & 499.00 & \multirow{3}{*}{111.000} & \multirow{3}{*}{0.005} \\
\hline & Group B & 20 & 16.05 & 321.00 & & \\
\hline & Total & 40 & & & & \\
\hline \multirow{3}{*}{$\begin{array}{l}\text { Walking } \\
\text { Time }\end{array}$} & Group A & 20 & 24.75 & 495.00 & \multirow{3}{*}{115.000} & \multirow{3}{*}{0.004} \\
\hline & Group B & 20 & 16.25 & 325.00 & & \\
\hline & Total & 40 & & & & \\
\hline \multirow{3}{*}{$\begin{array}{l}\text { Grip } \\
\text { Strength }\end{array}$} & Group A & 20 & 25.80 & 516.00 & \multirow{3}{*}{94.000} & \multirow{3}{*}{0.001} \\
\hline & Group B & 20 & 15.20 & 304.00 & & \\
\hline & Total & 40 & & & & \\
\hline
\end{tabular}

For comparison between Group A and Group B we have used Mann Whitney U test. It is observed from above observation that P-Values for fever and $\mathrm{Hb}$ are $>0.05$ hence there is no significant difference in effect of Group A and Group B on fever and Hb. P-Values for all other symptoms are less than 0.05 hence we conclude that there is significant difference in effect of Group A and Group B on, pain, swelling, stiffness, ESR, walking time and grip strength. 


\section{RESULT}

\section{DISCUSSION}

In the condition of pain, Khanda Shunthi is found more effective than Prasarini Avaleha because pain is the cardinal symptom of Vatadushti. Khanda shunthi is made from Ghrita, It is having Vatashamaka property so Khanda Sunthi may be more effective in Painful condition. In the condition of Shoth, Khnadasunthi is more effective than Prasarni Avaleha because in Khanda shunthi, Shunthi mixed in main Dravya and Prakshepa dravya. Shunthi is Vatakapha shamak and it shows anti-inflammatory action, Sokhanda shunthi may be more effective. In the condition of Stabdhata, Khanada Shunthi is more effective than Prasarini avaleha. In Aamvata stiffness present due to Vata and Kapha, Khandashunthi is having Ghrita and Shunthi. Ghrita is Vatashamak and Shunthi is Vatakaphashamak and Amapachaka so Khanda shunthi reduces the stiffness. Further we observed that, effect observed in Group A was 86.8\% while effect observed in Group B was $75.9 \%$. In the condition of fever, Khanda Shunthi is more effective than Prasarni Avaleha. In observational data, we found fever in all the patients. In Aamvata, fever present due to the Aam dosha and Sama Pitta. Shunthi is having Ghrita, Khandasharkara and Shunthi so its combination it subsides all Dosha and cure the fever. In the estimation of hemoglobin, Khanda shunthi is more effective than Prasarni Avaleha. In Amavatarasa dusthi is present due to this reason Uttrotar-dhatu i.e., from Raktadhatu to Shukradhatu do not form properly, Khanda shunthi has Ghrita and Shunthias the ingredients. Ghrita is Agnideepan and Shunthi is Aampachaka so because of proper digestion and assimilation of Ama it forms pure Rasa dhatu so Uttarotardhatu (next Dhatu) will form appropriate. So, Khanda shunthi increases haemoglobin.
Further we can observe that, Khanda sunthi is more effective in pain, swelling and stiffness condition so it increase walking time, so it increase grip strength.

\section{CONCLUSION}

The present clinical study has been undertaken to evolve the treatment procedure for Amavata and to evaluate the clinical efficacy of Khanda Shunthi and Prasarni Avaleha. The study has revealed that in group A where patients of Amavata received Khanda shunthi 10 gram twice a day for 60 days showed reduction of pain $82.8 \%$, swelling $75.4 \%$, stiffness $82.80 \%$, fever 86.80\% and improved $\mathrm{Hb} 81.1 \%$, ESR $81.5 \%$, walking time $83.3 \%$ and grip strength $87.3 \%$. The outcome is statistically significant. In group A where patients of Amavata received Prasarni Avaleha 10 gram twice a day for 60 days showed reduction of pain $66.7 \%$, swelling $67.8 \%$, stiffness $63.90 \%$, fever $75.9 \%$ and improved $\mathrm{Hb} 71.1 \%$, ESR $64.7 \%$, walking time $68.6 \%$ and grip strength $70 \%$. The outcome is statistically significant. Percent wise Group A treatment is more effective than Group B for all assessment criteria. From the aforesaid observations, it can be resolved that Khanda Shunthi because of its Rasayana and Deepana properties improves the nonspecific immunity against Amavata. Finally it can be concluded that Amavata patients have got significant results with these drugs. Khanda sunthi is more effective than Prasarni Avaleha. To draw final conclusions, the trial requires more clinical data.

\section{REFRENCES}

1. K.V.Krishna Das, Text book of Medicine, Fifth edition, 2008 Jaypee brothers medical Publisher New Delhi, Section 12, page no. 692.

2. Vasu V and Vasu H, (editors). Shabda Kalpa Druma Varanasi, Uttar Pradesh: Chaukhamba Sanskrit series; 1967. Radhakant dev., part 4.

3. Shastri, Sudarsana, Madhav Nidan, Vidyotini Hindi Commentary, Chaukhamba Sanskrit Sansthan Varanasi. 2006.

\section{Cite this article as:}

Anu Gupta, Kalpana Patni. A Comparative Clinical Study of Khanda Shunthi and Prasarni Avleha in the Management of Amavata with Special Reference to Rheumatoid Arthritis International Journal of Ayurveda and Pharma Research. 2021;9(Suppl 1):20-26.

https://doi.org/10.47070/ijapr.v9iSuppl1.2026

Source of support: Nil, Conflict of interest: None Declared
*Address for correspondence Dr. Kalpana Patni

Assistant Professor

Department of Kaumarabhritya

FoA IMS BHU, Varanasi.

Email: kalpana.patni@gmail.com Ph.No : 9456140578

Disclaimer: IJAPR is solely owned by Mahadev Publications - dedicated to publish quality research, while every effort has been taken to verify the accuracy of the content published in our Journal. IJAPR cannot accept any responsibility or liability for the articles content which are published. The views expressed in articles by our contributing authors are not necessarily those of IJAPR editor or editorial board members. 